\title{
Kebijakan Penguatan Kewajiban Alih Pengetahuan Tenaga Kerja Asing
}

\author{
Solechan \\ Fakultas Hukum Universitas Diponegoro \\ J1.Prof.Soedarto, SH Tembalang Semarang \\ Solechan_fh@gmail.com
}

\begin{abstract}
This study aims to find out the policy of transfer of knowledge of foreign workers in Indonesia. In addition, to know the policy of transfer of knowledge on the labor legislation law has guaranteed the implementation of knowledge transfer in the framework of the protection of Indonesian labor force. Research method in this research is legal research (legal research), that is by using library research data (library research), using statutory approach approach (statutory approach). The results showed that the transfer of knowledge has been regulated in the legislation in Indonesia. But the arrangement is still very general and sectoral.
\end{abstract}

Keywords: Transfer of Knowledge, Manpower, Policy

\begin{abstract}
Abstrak
Penelitian ini bertujuan untuk mengetahui kebijakan alih pengetahuan tenaga kerja asing di Indonesia. Selain itu juga, untuk mengetahui kebijakan alih pengetahuan pada peraturan perundang-undang tentang ketenagakerjaan telah menjamin terlaksananya alih pengetahuan dalam rangka perlindungan tenagakerja Indonesia. Metode penelitian dalam penelitian ini adalah penelitian hukum (legal research), yaitu dengan menggunakan data penelitian kepustakaan (library research), menggunakan pendekatan peraturan perundang undangan (statutory approach). Hasil penelitian menunjukan bahwa alih pengetahuan telah diatur dalam peraturan perundang-undangan di Indonesia. Namun pengaturannya tersebut masih sangat bersifat umum dan sektoral.
\end{abstract}

Kata Kunci: Alih Pengetahuan, Ketenegakerjaan, Kebijakan

\section{A. Pendahuluan}

Pembangunan Industri merupakan salah satu pilar pembangunan perekonomian nasional, yang diarahkan dengan menerapkan prinsip-prinsip pembangunan Industri yang didasarkan pada aspek pembangunan ekonomi, sosial, dan lingkungan hidup. Pembangunan Industri telah mencapai kondisi yang mana batas-batas negara dan yurisdiksional tidak menjadi lebih penting daripada efisiensi, sehingga peningkatan daya saing secara global mutlak dilaksanakan. Upaya peningkatan daya saing industri memerlukan strategi di setiap langkah dan tahapan pada tiaptiap aspek demi menjamin adanya perencanaan, pelaksanaan hingga evaluasi dengan hasil yang diharapkan.

Salah satu strategi yang perlu dipersiapkan adalah pada aspek tenaga kerja. Persoalan tentang penempatan tenaga kerja, sertifikasi tenaga kerja dan jaminan sosial tenaga kerja menjadi sedikit permasalahan pada bidang tenaga kerja yang membutuhkan penyelesaian dan 
strategi utamanya secara yuridis untuk diselesaikan dengan campur tangan negara melalui pemerintah sebagai regulator dibidang ketenagakerjaan. ${ }^{1}$ Terkait dengan liberalisasi perindustrian, persoalan pokok yang perlu diselesaikan dan dirancang strateginya salah satunya adalah penggunaan tenaga kerja asing di Indonesia.

Penggunaan tenaga kerja asing di Indonesia tidak terlepas dari adanya 2 (dua) faktor sebagai pendorongnya. Pertama, merupakan sebuah tuntutan bagi Indonesia sebagai salah satu anggota WTO dengan adanya perdagangan bebas untuk membuka bursa tenaga kerja di Indonesia. Kedua, masih rendahnya angka tenaga kerja nasional yang memiliki keahlian atau keterampilan yang kompetitif baik untuk kebutuhan dalam negeri maupun luar negeri dibandingkan dengan rasio jumlah penduduk Indonesia. Oleh karena salah satunya faktor-faktor tersebut, menjadi sebuah keniscayaan agar pemerintah sebagai regulator untuk menyesuaikan perdagangan bebas tenaga kerja dengan kebutuhan dan tuntutan untuk tetap memprioritaskan tenaga kerja nasional. Khususnya pada faktor kedua, sudah sepatutnya terdapat kerangka yuridis sebagai sebuah strategi demi mengoptimalkan penggunaan tenaga kerja asing di Indonesia demi kesejahteraan umum.

Pada dasarnya penggunaan tenaga kerja asing adalah dilarang, namun diaturnya penggunaan tenaga kerja asing dalam peraturan perundang-undangan dengan berbagai persyaratan ketat mengisyaratkan bahwa larangan tersebut dikesampingkan. Berdasarkan pada Undang-Undang Dasar Tahun 1945 sebagaimana disebutkan pada pembukaannya bahwa negara melalui pemerintah memiliki tujuan salah satunya untuk memajukan kesejahteraan umum, maka telah terdapat landasan filosofis terkait bagaimana seharusnya pemerintah merumuskan kebijakan strategis dibidang tenaga kerja asing. Oleh karena dikesampingkannya larangan penggunaan tenaga kerja asing di Indonesia dikaitkan dengan cita-cita luhur yang wajib diwujudkan Pemerintah Indonesia maka penggunaan tenaga kerja asing di Indonesia singkatnya harus membawa dampak dan manfaat yang sebesar-besarnya. ${ }^{2}$.

Pada hakikatnya, adanya tenaga kerja asing di Indonesia bertujuan untuk menularkan segala keahliannya demi meningkatkan kualitas dan daya saing tenaga kerja nasional. Pada Peraturan Ketenagakerjaan di dasarkan pada Undang Undang Nomor 13 Tahun 2003 tentang ketenagakerjaan, mekanisme dalam mengoptimalkan peningkatan kualitas tenaga kerja nasional dengan adanya tenaga kerja asing dilakukan dengan metode yang disebut dengan istilah alih keahlian atau juga dalam bisnis perbankan dikenal dengan istilah alih pengetahuan. Dalam bisnis perbankan alih pengetahuan merupakan komitmen yang diberikan oleh Indonesia dalam rangka WTO, mensyaratkan bahwa pihak asing dibolehkan memperkerjakan tenaga ahli asing di perbankan dengan ketentuan setiap satu tenaga ahli diwajibkan untuk mengangkat 2 (dua) understudies. Akan tetapi persyaratan understudies ini tidak berjalan sebagaimana yang diharapkan. Salah satu penyebabnya adalah tidak jelasnya ketentuan mengenai persyaratan dan atau kualifikasi tentang ahli.

Dalam era yang semakin liberal, melarang masuknya tenag kerja asing (TKA) apalagi dalam kaitannya dengan intra agencies transfer yaitu pembeli perusahaan dibolehkan untuk membawa pimpinan dan atau tenaga ahli yang dibutuhkannya akan membawa dampak ekonomi politik dan hukum yang negatif. Satu hal yang harus diperhatikan dalam kaitannya dengan TKA adalah tidak adanya standar keahlian yang berlaku. Standar keahlian ini diperlukan untuk menyaring TKA yang datang ke Indonesia. ${ }^{3}$

\footnotetext{
${ }^{1}$ Guus Heerma Van Voss dalam Bab-Bab Tentang Hukum Perburuhan Indonesia ed. Guus Heerma Van Voss dan Surya Tjandra , (Pustaka Larasan: Denpasar, 2012), halaman 6

${ }^{2}$ Naskah akademik Rancangan Undang-Undang Jasa Konstruksi, halaman 32

${ }^{3}$ Tim Perbankan dan Enquiry Point, Tenaga Kerja Asing Pada Perbankan Nasional, Buletin Hukum Perbankan Dan Kebanksentralan, Volume 5, Nomor 3, Desember 2007, di unduh laman: http://www.bi.go.id/id/publikasi/lain/hukumperbankan/Documents/042c064ba0074ff0aef68754e9f3e2c702_TKA2. pdf
} 
Setandar keahlian ini seharunya diserahkan kepada oraganisasi profesi, bukan justru pemerintah mengeluarkan penetapan persyaratan persyaratan tertentu.

Sedangkan Pada Industri Jasa Konstruksi, diundangkannya Undang-Undang Nomor 2 Tahun 2017 Tentang Jasa Konstruksi yang mencabut Undang-Undang Nomor 18 Tahun 1999 Tentang Jasa Konstruksi memberikan perubahan-perubahan baru pada nafas dan kerangka yuridis industri jasa konstruksi tidak terkecuali pada aspek ketenagakerjaan. Khususnya pada bidang tenaga kerja, Undang-Undang Nomor 2 Tahun 2017 tersebut memberikan penegasan pada tenaga kerja asing dengan segala kewajibannya. Kemudian tahapan dimana tenaga kerja asing memberikan memberikan pengetahuan kepada tenaga kerja nasional kemudian disebut dengan istilah alih pengetahuan.

Alih pengetahuan dilakukan melalui pelatihan-pelatihan yang dilakukan oleh tenaga kerja asing di Indonesia kepada tenaga kerja nasional. Ketentuan tersebut telah secara tegas diatur dalam Undang-Undang Nomor 13 Tahun 2003 tentang Ketenagakerjaan, namun apabila dikaitkan dengan Undang-Undang Jasa Konstruksi perlu adanya penelaahan secara mendalam terkait harmonisasi norma masing-masing peraturan mengingat baru diundangkannya UndangUndang Jasa Konstruksi. Adapun dengan fakta tersebut dibutuhkan suatu pengkajian mendalam terkait kesesuaian pengaturan kewajiban alih pengetahuan dalam peraturan umum dengan peraturan khusus sektoral dalam hal ini jasa konstruksi.

Demi terwujudnya hakikat dari penggunaan tenaga kerja asing di indonesia khususnya pada industri jasa konstruksi untuk meningkatkan kualitas dan daya saing tenaga kerja konstruksi nasional maka perlu adanya regulasi yang menjamin terlaksananya tujuan tersebut. Mekanisme alih pengetahuan yang digunakan sebagai metode peningkatan kualitas bagi tenaga kerja nasional diatur dalam pelbagai peraturan perundang-undangan yang saling terpisah. Oleh karena itu penelitian ini akan mengkaji bagaimana ketentuan alih pengetahuan oleh tenaga kerja asing ditinjau dari peraturan perundang-undangan tentang ketenagakerjaan secara umum dan ditinjau dari peraturan perundang-undangan tentang jasa konstruksi secara khusus. Penelitian ini juga nantinya akan melakukan telaahan terhadap ketentuan sanksi administratif akibat tidak terlaksananya kewajiban alih pengetahuan dalam peraturan perundang-undang tentang ketenagakerjaan dan tentang jasa konstruksi di Indonesia.

\section{Rumusan Masalah}

Berdasarkan uraian latar belakang tersebut maka, Penelitian ini akan menguraikan permaslahan adalah Bagaimana Kebijakan Alih Pengetahuan Diatur Dalam Peraturan Perundang-Undangan di Indonesia?

\section{A. Pembahasan}

\section{Istilah Tenaga Kerja Asing}

Apa yang dimaksud dengan tenaga kerja asing telah diformulasikan secara yuridis dalam peraturam perundang-undangan sehingga telah menjadi terminologi hukum yang pasti. Dalam Undang-Undang No 13 Tahun 2003 tentang Ketenagakerjaan definisi tenaga kerja asing telah diatur khususnya pada pasal 1 angka 13. Pasal tersebut menyatakan:Tenaga kerja asing adalah warga negara asing pemegang visa dengan maksud bekerja di wilayah Indonesia.

Definisi yang sama persis juga terdapat dalam peraturan pelaksana dari UU No 13 Tahun 2003. Peraturan yaitu pasal 1 angka 1 Peraturan Presiden No 72 Tahun 2014 serta pasal 1 angka 1 Peraturan Menteri Ketenagakerjaan No 16 Tahun 2015. Adanya terminologi hukum yang pasti khususnya dari peraturan umum hingga peraturan pelaksana yang terdapat pada saat ini mengenai apa itu tenaga kerja asing tidak terjadi pada masa sebelumnya. Pada peraturan yang berlaku sebelum Undang-Undang No 13 Tahun 2003 diundangkan tidak memberikan definisi tentang apa itu tenaga kerja asing melainkan hanya memberikan definisi tentang istilah orang asing. Undang-Undang No 3 tahun 1958 tentang Penempatan Tenaga 
Kerja Asing tepatnya pasal 1 huruf a menyatakan: orang asing, ialah tiap orang bukan warga negara Republik Indonesia.

Selain berdasarkan definisi yang berangkat dari peraturan perundang-undangan, para sarjana juga memberikan definisi tentang tenaga kerja asing. Salah satunya adalah Abdul Khakim yang memberikan pengertian bahwa tenaga kerja asing adalah tiap orang bukan warga negara Indonesia yang mampu melakukan pekerjaan, baik di dalam maupun di luar hubungan kerja, guna menghasilkan jasa atau barang untuk memenuhi kebutuhan masyarakat. ${ }^{4}$

Berdasarkan dari definsi baik dari peraturan perundang-undangan serta pendapat ahli yang telah dipaparkan, dapat ditemukan satu penekanan yang menjadi unsur fundamental tenaga kerja asing. Unsur fundamental yang dimaksud adalah terletak pada persoalan kewarganegaraan seorang pekerja. Perkembangan pada definisi tenaga kerja asing pada masa sebelumnya hingga saat ini terletak pada pendefinisian tenaga kerja asing yang telah dikhususkan pada tenaga kerja serta kewarganegaraannya pada satu definisi yang integral.

\section{Mekanisme Penggunaan Tenaga Kerja Asing}

Mekanisme penggunaan tenaga kerja asing sesuai dengan peraturan perundangundangan yang berlaku diatur mulai dari undang-undang hingga pada tingkat peraturan menteri ketenagakerjaan. Secara umum dapat dijelaskan bahwa pembatasan secara luas diatur dalam undang-undang. Sementara pembatasan umum tersebut sedikit dijelaskan lebih lanjut dalam peraturan presiden dan bagaimana rincinya diatur dalam peraturan menteri ketenagakerjaan. Bisa dikatakan secara khusus mekanisme penggunaan tenaga kerja asing pengaturannya secara utuh terletak pada peraturan menteri ketenagakerjaan.

Dalam UU No 13 Tahun 2003 ketentuan tentang tenaga kerja asing diatur dalam pasal 42 hingga pasal 49. Bagaimana kebijakan tentang tenaga kerja asing pada peraturan ini terpampang jelas pada awal pengaturannnya di pasal 42 ayat (1) yang menyatakan: Setiap pemberi kerja yang mempekerjakan tenaga kerja asing wajib memiliki izin tertulis dari Menteri atau pejabat yang ditunjuk.

Pada dasarnya penggunaan tenaga kerja asing tidaklah diperkenankan, akan tetapi dengan kebutuhan yang tidak dapat ditunda serta adanya instrumen hukum internasional yang memungkinkan kemudian tenaga kerja asing dapat digunakan di Indonesia. Latar belakang yang demikian menjadi menemukan relevansinya terhadap ketentuan pasal 42 ayat (1) yang menghendaki adanya kontrol atas penggunaan tenaga kerja asing oleh pemberi kerja di Indonesia. Latar belakang tersebut secara halus diterangkan dalam penjelasan pasal 42 ayat (1) yang menerangkan: Perlunya pemberian izin penggunaan tenaga kerja warga negara asing dimaksudkan agar penggunaan tenaga kerja warga negara asing dilaksanakan secara selektif dalam rangka pendayagunaan tenaga kerja Indonesia secara optimal. Sesungguhnya ada peraturan yang lebih lanjut kemudian pada dasarnya menjadi pelaksanaan dari maksud dan tujuan dari substansi pasal 42 ayat (1) ini.

Pada pasal-pasal selanjutnya terkandung beberapa pembatasan yang berlaku bagi tenaga kerja asing di indonesia. Pertama, tenaga kerja asing hanya dapat bekerja selain pada perusahaan perorangan. Hal tersebut diatur dalam pasal 42 ayat (2) yang menyatakan: Pemberi kerja orang perseorangan dilarang mempekerjakan tenaga kerja asing.

Kedua, tenaga kerja asing tidak dapat melakukan pekerjaan dalam sembarang jabatan di Indonesia. Adapun juga tidak dapat melakukan pekerjaan dalam waktu tak tentu. Pembatasan tersebut ditegaskan keberlakuannya dalam pasal 42 ayat (4) yang menyatakan: Tenaga kerja asing dapat dipekerjakan di Indonesia hanya dalam hubungan kerja untuk jabatan tertentu dan waktu tertentu.

\footnotetext{
${ }^{4}$ Abdul Khakim, 2009, Dasar-Dasar Hukum Ketenagakerjaan Indonesia, Citra Aditya Bakti, Bandung, h.27
} 
Bagaimana pengaturan ketentuan tersebut dalam pasal 42 ayat (5) dijelaskan akan diatur lebih lanjut pada peraturan presiden. Ketiga, tenaga kerja asing dilarang untuk menduduki jabatan personalia atau jabatan tertentu. Ketentuan tersebut sesungguhnya merupakan sebagian kecil dari implementasi ketentuan pasal 42 ayat (4). Pembatasan tersebut diatur dalam pasal 46 ayat (1) yang menyatakan: Tenaga kerja asing dilarang menduduki jabatan yang mengurusi personalia dan/atau jabatan-jabatan tertentu. Bagaimana hal tersebut diatur ditentukan bahwa akan diatur lebih lanjut dalam keputusan menteri sebagaimana disebutkan dlam pasal 46 ayat (2).

Selain mengatur tentang rambu-rambu umum apa yang tidak diperbolehkan bagi tenaga kerja asing, undang-undang mengatur pula secara umum mekanisme penggunaan tenaga kerja asing. Adapun pasal 43 mengatur secara umum tentang mekanisme apabila pemberi kerja ingin menggunakan tenaga kerja asing. Pada pokoknya pasal 43 mengatur bahwa pemberi kerja dalam menggunakan tenaga kerja asing wajib memiliki Rencana Penggunaan Tenaga Kerja Asing (RPTKA). Penegasan tersebut diatur pada pasal 43 ayat (1) yang menyatakan: Pemberi kerja yang menggunakan tenaga kerja asing harus memiliki rencana penggunaan tenaga kerja asing yang disahkan oleh Menteri atau pejabat yang ditunjuk.

Lalu apa saja yang terdapat dalam RPTKA diatur dalam pasal 43 ayat (2) serta siapa yang berhak atas pengaturannya diatur dalam pasal 43 ayat (4) yang mnyatakan:

Ketentuan mengenai tata cara pengesahan rencana penggunaan tenaga kerja asing diatur dengan Keputusan Menteri. Adapun berdasarkan substansi dan bunyi pasal tersebut diketahui bahwa bagaimana mekanisme lebih lanjut tentang RPTKA dapat ditemukan dalam peraturan menteri.

Berdasarkan pada beberapa uraian tersebut, dapat diketahui pengaturan tenaga kerja asing dalam undang-undang masih cukup minim. Tecatat beberapa pasal pada undangundang terbatas hanya menjelaskan batasan-batasan pokok terhadap penggunaan tenaga kerja asing serta mekanisme sederhana dari penggunaan tenaga kerja asing. Hal tersebut kemudian dijembatani undang-undang dengan mengatur kewajiban pengaturan lebih lanjut dalam aturan pelaksana. Pasal 49 menyatakan. Ketentuan mengenai penggunaan tenaga kerja asing serta pelaksanaan pendidikan dan pelatihan tenaga kerja pendamping diatur dengan Keputusan Presiden Oleh karena hal tersebut perlu kemudian untuk menelaah peraturan pelaksananya secara mendalam demi memperoleh suatu gambaran utuh. Berdasarkan pada pengaturan dalam Peraturan Presiden No 72 Tahun 2014 yang berdasarkan konsiderannya merupakan pelaksanaan dari pasal 49 UU No 13 Tahun 2003 ditemukan pengaturan yang lebih mengatur secara jelas mekanisme penggunaan tenaga kerja asing. Adapun dalam Perpres No 72 Tahun 2014 dijelaskan runtutan dari RPTKA hingga bagaimana kelanjutan dari adanya RPTKA. Pendek kata, Perpres No 72 Tahun 2014 telah mengakomodasi mekanisme serta alur proses izin penggunaan tenaga kerja asing.

Perpres No 72 Tahun 2014 mengatur bahwa dalam menggunakan tenaga kerja asing, pemberi kerja membutuhkan Rencana Penggunaan Tenaga Kerja Asing (RPTKA) serta Izin Memperkerjakan Tenaga Kerja Asing (IMTA). Dimana kedua syarat tersebut merupakan izin berangkai dimana IMTA hanya dapat diperoleh dengan RPTKA yang telah disahkan. Ketentuan tersebut ditegaskan dalam pasal 5 ayat (3) yang menyatakan: RPTKA sebagaimana dimaksud pada ayat (2) digunakan sebagai dasar untuk memperoleh IMTA. Sementara dari awal, mekanismenya pemberi kerja wajib memperoleh RPTKA yang telah disahkan oleh menteri ketenagakerjaan. Ketentuan tersebut diatur dalam pasal 5 ayat (1) yang menyatakan: Setiap Pemberi Kerja TKA harus memiliki RPTKA yang disahkan oleh Menteri atau pejabat yang ditunjuk sebelum mempekerjakan TKA. 
Sementara untuk memperoleh pengesahan RPTKA, pemberi kerja perlu mengajukan permohonan tertulis yang diatur dalam pasal 5 ayat (2) yang menyatakan: Untuk memiliki RPTKA sebagaimana dimaksud pada ayat (1), Pemberi Kerja TKA harus mengajukan permohonan secara tertulis kepada Menteri atau pejabat yang ditunjuk.

Setelah memiliki RPTKA yang telah disahkan, pemberi kerja dengan RPTKA yang telah disahkan tersebut kemudian mengajukan permohonan IMTA. IMTA diterbitkan oleh menteri ketenagakerjaan. Hal tersebut ditegaskan dalam pasal 8 ayat (1) yang menyatakan:

Setiap Pemberi Kerja TKA wajib memiliki IMTA yang diterbitkan oleh Menteri atau pejabat yang ditunjuk. Hal-hal tersebutlah yang terkandung dalam Perpres No 72 Tahun 2014. Kemudian bagaimana lebih lanjutnya, dalam pasal 10 diatur akan diregulasikan oleh peraturan menteri. Pasal 10 menyatakan: Ketentuan lebih lanjut mengenai tata cara penggunaan TKA diatur dengan Peraturan Menteri.

Ketentuan lebih lanjut yang mengatur mekanisme rinci penggunaan tenaga kerja asing adalah Peraturan Menteri Ketenagakerjaan No 16 Tahun 2015 yang telah dirubah dengan Peraturan Menteri Ketenagakerjaan No 35 Tahun 2015. Pada peraturan menteri tersebut kemudian secara lebih detail diatur tentang RPTKA, IMTA serta pemecahan kembali bidang-bidang yang dalam industrinya daapat menggunakan tenaga kerja asing.

Pada ketentuan peraturan presiden telah diatur bahwa pemberi kerja yang akan menggunakan tenaga kerja asing memerlukan RPTKA dengan mengajukan permohonan ke menteri, adapun pada Permen No 16 Tahun 2015 khususnya pasal 6 diatur cara permohonan tersebut. Pasal 6 ayat (1) menjelaskan bahwa pemberi kerja yang ingin mendapatkan RPTKA harus mengajukan permohonan secara online kepada direktur jenderal pembinaan penempatan tenaga kerja dan perluasan kesempatan kerja melalui direktur penggendalian penggunaan tenaga kerja asing. Adapun pasal tersebut juga mengatur apa saja yang harus diunggah pemberi kerja secara online tersebut.

Adapun selanjutnya mekanisme penilaian kelayakan atas permohonan RPTKA yang telah diajukan oleh pemberi kerja diatur kemudian di pasal 7. Sesungguhnya pada pasal 7 tidak diatur secara jelas bagaimana mekanisme penilaian terhadap kelayakan suatu permohonan. Pada pasal tersebut hanya ditekankan pada keharusan terhadap kelengkapan dokumen pada saat pengajuan RPTKA. Adapun lebih jauh, penilaian selanjutnya pada pasal 7 ayat (3) diatur kesesuain posisi jabatan yang akan diduduki oleh tenaga kerja asing terhadap kesesuaiannya dengan apa yang diatur dalam perundang-undangan. Selain kedua hal tersebut pada pasal 7 ayat (5) hanya mengatur bahwa penilaian didasarkan pada ketentuan peraturan-perundang-undangan. Terhadap aturan yang demikian, besar resiko akan timbulnya suatu proses administrasi yang dapat saja merugikan pemohon RPTKA.

Atas permohonan tersebut diatur dalam pasal 8 apabila telah memenuhi persyaratan maka dirjen atau direktur harus menerbitkan keputusan pengesahan RPTKA. Pasal 10 mengatur lebih lanjut kewenangan penerbitan keputusan tersebut. Pada pasal 10 huruf a diatur bahwa dirjen menerbitkan keputusan terhadap pemberi kerja yang memperkerjakan tenaga kerja asing sebanyak 50 orang atau lebih. Sementara pada pasal 10 huruf b diatur bahwa direktur menerbitkan keputusan terhadap pemberi kerja yang memperkerjakan tenaga kerja asing sebanyak kurang dari 50 orang.

Selain diatur tentang RPTKA secara umum, peraturan menteri juga kemudian mengatur RPTKA khusus. RPTKA khusus yang dimaksud adalah RPTKA selain RPTKA yang telah diatur sebelumnya yang memiliki kegunaan untuk sesuatu keadaan yang khusus atau untuk bidang industri khusus. Tercatat sesutu yang khusus tersebut yaitu RPTKA untuk pekerjaan yang bersifat darurat dan mendesak serta RPTKA untuk pekerjaan yang bersifat sementara. Adapun perbedaan kedua RPTKA khusus tersebut dengan RPTKA pada umumnya terletak pada apa yang wajib diunggah oleh pemberi kerja serta lampiran lainnya mengikuti kebutuhan atas sesuatu yang khusus tersebut. Selain kedua RPTKA tersebut 
terdapat lagi beberapa RPTKA yang khusus diatur untuk bidang industri tertentu. RPTKA yang dimaksud yaitu RPTKA untuk KEK dan kawasan perdagangan bebas dan pelabuhan bebas, wilayah perairan, usaha jasa impresariat, pemandu nyanyi/karaoke. Serupa dengan RPTKA khusus sebelumnya, RPTKA untuk beberapa bidang tersebut perbedaannya hanya terletak pada apa yang wajib diunggah oleh pemberi kerja serta lampiran lainnya mengikuti kebutuhan atas industri khusus tersebut.

Secara prinsip, setelah RPTKA disahkan dengan adanya surat keputusan, langkah selanjutnya yang diperlukan untuk menyelesaikan proses perizinan penggunaan tenaga kerja asing adalah dengan memohonkan IMTA. Pasal 38 ayat (1) mengatur bahwa pengajuan IMTA dilakukan secara online kepada direktur penggendalian penggunaan tenaga kerja asing dengan mengunggah beberapa persyaratan yang salah satunya diatur pada huruf $b$ adalah surat keputusan pengesahan RPTKA. Oleh karena tersebut penerbitan IMTA yang digantungkan pada rampungnya RPTKA menggambarkan pada prinsipnya keduanya termasuk dalam apa yang biasa disebut keputusan tata usaha negara berangkai.

Pentingnya terdapat IMTA oleh karena dokumen ini merupakan dasar bagi diterbitkannya izin-izin pribadi bagi si tenaga kerja asing. Pasal 39 ayat (3) secara jelas mengatur bahwa IMTA merupakan dasar bagi disetujuinya visa, izin dan perpanjangan izin tinggal terbatas (ITAS), alih status ITAS menjadi izin tinggal tetap (ITAP) maupun perpanjangan ITAP. Lebih lanjut serupa dengan RPTKA yang memiliki bentuk-bentuk khususnya, IMTA juga mengikuti bentuk-bentuk khusus persis layaknya RPTKA. Oleh karena RPTKA khusus tersebut juga harus diikuti dengan IMTA yang khusus pula.

\section{Kewajiban Tenaga Kerja Asing}

Pada tahun 2015 Kementerian Tenaga Kerja dan Transmigrasi (Kemenakertrans) menerbitkan aturan baru terkait tata cara penggunaan Tenaga Kerja Asing (TKA) di Indonesia yaitu Peraturan Menteri Ketenagakerjaan Nomor 35 Tahun 2015 (Permenaker 35 tahun 2015). Permenaker 35/2015 ini menghilangkan, menambah, dan mengubah beberapa pasal dalam Peraturan Menteri Petenagakerjaan Nomor 16 Tahun 2015 ("Permenaker 16/2015"). Keluarnya Permenaker 35/2015 ini menimbulkan polemik setidaknya terkait 2 (dua) hal. Pertama, Permenaker 35/2015 ini dikeluarkan saat Permenaker 16/2015 baru mulai dirasakan efektif implementasinya di lapangan. Berdasarkan pengalaman Easybiz di lapangan, Permenaker 16/2015 baru efektif 3 (tiga) bulan setelah diterbitkan.

Keluarnya Permenaker 35/2015 ini dikhawatirkan menimbulkan kebingungan di lapangan, terutama pada aplikasi permohonan RPTKA (Rencana Penggunaan Tenaga Kerja Asing) dan IMTA (Izin Memperkerjakan Tenaga Kerja Asing) yang baru masuk pada periode antara September dan Oktober. Kedua, polemik yang timbul dari hilangnya, bertambahnya, dan berubahnya beberapa pasal dalam Permenaker 16/2015 yaitu sebagai berikut :

a. Penghapusan Rasio Jumlah TKA Dengan Tenaga Kerja Lokal

Dalam Pasal 3 Permenaker 16/20015 diatur bahwa perusahaan yang mempekerjakan 1 (satu) orang TKA harus dapat menyerap sekurang-kurangnya 10 (sepuluh) orang tenaga kerja lokal pada perusahaan yang sama. Memang ada pengecualian atas rasio ini jika TKA tersebut akan dipekerjakan untuk posisi tertentu, untuk pekerjaan yang sifatnya darurat dan mendesak, untuk pekerjaan yang sifatnya sementara, dan/atau untuk usaha jasa impresariat. Pasal 3 Permenaker 16/2015 ini dihapuskan oleh Permenaker 35/2015. Penghapusan pasal ini artinya menghapuskan aturan mengenai rasio jumlah TKA dengan tenaga kerja lokal.

Penghapusan diatas dikhawatirkan menghilangkan kesempatan terjadinya alih pengetahuan dan alih teknologi dari TKA ke tenaga kerja lokal. Meskipun dalam Pasal 65 Permenaker 16/2015 disebutkan bahwa perusahaan pemberi kerja dapat 
menugaskan TKA untuk melakukan alih teknologi dan keahlian di lembaga pendidikan dan pelatihan, namun bisa jadi hal ini tidak dilaksanakan jika tidak diwajibkan secara jelas dalam peraturan perundang-undangan. Apalagi saat ini Keputusan Direktorat Jenderal yang mengatur mengenai pendampingan TKA oleh tenaga kerja lokal untuk alih teknologi dan keahlian belum diterbitkan sebagaimana disebutkan dalam Pasal 66A Permenaker 35/2015.

Di sisi yang lain, penghapusan rasio ini memberikan kemudahan bagi perusahaan yang berbisnis di Indonesia untuk memperkerjakan TKA secara lebih murah karena tidak perlu memperkerjakan lebih banyak tenaga kerja lokal dan tidak adanya kewajiban melakukan pelatihan pada tenaga kerja lokal.

b. Larangan Bagi PMDN Untuk Memperkerjakan TKA Sebagai Komisaris Dalam Permenaker 16/2015 tidak ada larangan bagi perusahaan PMDN (Penanaman Modal Dalam Negeri) untuk memperkerjakan TKA sebagai Komisaris. Namun dalam Permenaker 35/2015 ditambahkan pasal baru antara Pasal 4 dan Pasal 5, yaitu Pasal 4A. Di Pasal 4A ini diatur bahwa perusahaan yang berbentuk PMDN dilarang memperkerjakan TKA dengan jabatan Komisaris. Larangan ini menambah daftar pekerjaan yang tidak boleh diduduki TKA. Sebelumnya dalam Undang-Undang Nomor 13 Tahun 2003 tentang Ketenagakerjaan hanya diatur bahwa yang dilarang adalah jabatan yang mengurusi personalia atau sumber daya manusia.

c. Penghapusan dan Perubahan Aturan Mengenai Pemberian RPTKA dan IMTA Untuk Pekerjaan Yang Bersifat Sementara

Dalam Permenaker 16/2015 diatur bahwa izin RPTKA dan izin IMTA untuk pekerjaan sementara diberikan untuk: 1. Memberikan bimbingan, penyuluhan, dan pelatihan dalam penerapan dan inovasi teknologi industri untuk meningkatkan mutu dan desain produk industri serta kerja sama pemasaran luar negeri bagi Indonesia; 2. Pembuatan film yang bersifat komersial dan telah mendapat izin dari instansi yang berwenang; 3. Memberikan ceramah; 4. Mengikuti rapat yang diadakan dengan kantor pusat atau perwakilan di Indonesia; 5. Melakukan audit, kendali mutu produksi, atau inspeksi pada cabang perusahan di Indonesia; 6. TKA dalam uji coba kemampuan dalam bekerja; 7. Pekerjaan yang sekali selesai; dan 8 . Pekerjaan yang berhubungan dengan pemasangan mesin, elektrikal, layanan purna jual, atau produk dalam masa penjajakan usaha.

Sementara Permenaker 35/2015 mengatur pemberian izin RPTKA dan izin IMTA untuk pekerjaan yang sementara diberikan untuk: 1. Pembuatan film yang bersifat komersial dan telah mendapat izin dari instansi yang berwenang; 2 . Melakukan audit, kendali mutu produksi, atau inspeksi pada cabang perusahan di Indonesia untuk jangka waktu lebih dari 1 (satu) bulan; dan 3. Pekerjaan yang berhubungan dengan pemasangan mesin, elektrikal, layanan purna jual, atau produk dalam masa penjajakan usaha.

\section{d. Penghapusan Keharusan Memiliki IMTA Bagi TKA Yang Tidak Berdomisili Di Indonesia}

Di Pasal 37 Permenaker 16/205 diatur bahwa perusahaan pemberi kerja bagi TKA wajib mengurus izin IMTA, terlepas dari jabatan apapun yang akan diberikan pada TKA tersebut. Pengecualian kewajiban ini hanya berlaku bagi pemberi kerja yang berupa perwakilan negara asing yang mempekerjakan TKA sebagai pegawai diplomatik dan konsuler. Permenaker 35/2015 menambahkan pengecualian kewajiban memiliki IMTA ini bagi perusahaan pemberi kerja yang memperkerjakan TKA sebagai anggota Direksi, anggota Dewan Komisaris atau anggota Pembina, anggota Pengurus, dan anggota Pengawas yang berdomisili di luar negeri. Sementara bagi TKA yang berdomisili di Indonesia tetap wajib untuk memiliki IMTA. 
Penambahan pengecualian ini menimbulkan pertanyaan mengenai izin yang harus dikantongi jika TKA yang berdomisili di luar negeri tersebut kemudian datang ke Indonesia untuk urusan pekerjaan yang sementara seperti rapat, memberikan ceramah, atau melakukan pekerjaan lain yang bisa sekali selesai dalam waktu singkat. Jangan sampai orang asing yang datang dengan visa turis kemudian malah melakukan pekerjaan di Indonesia. Memang, di satu sisi penghapusan kewajiban mengurus izin IMTA ini membantu mengurangi anggaran dan waktu yang harus disiapkan perusahaan dalam mengurus izin bagi TKA yang hendak diperkerjakannya, kecuali bagi perusahaan yang telah mengajukan permohonan IMTA pada periode Oktober sebelum terbitnya Permenaker 35/2015. Tapi di sisi lain perbedaan perlakuan terhadap TKA berdasarkan domisili ini juga berpotensi mengurangi pendapatan negara dari dana kompensasi penggunaan tenaga kerja asing.

\section{e. Penghapusan Aturan Mengenai Konversi Iuran DKP-TKA Ke Rupiah}

Dalam Pasal 40 ayat (2) Permenaker 16/2015 diatur bahwa DKP-TKA yang dibayarkan harus dikonversi ke Rupiah. Permenaker 35/2015 menghapuskan ketentuan ini. Penghapusan ini bertentangan dengan Undang-Undang Nomor 7 Tahun 2011 tentang Mata Uang ("UU 7/2011"). Dalam Pasal 21 UU 7/2011 diatur bahwa mata uang Rupiah wajib digunakan dalam tiap transaksi yang memiliki tujuan pembayaran dan penyelesaian kewajiban yang harus dipenuhi dengan uang. Pengecualian atas kewajiban menggunakan Rupiah hanya berlaku atas: 1 . Transaksi tertentu dalam rangka pelaksanaan APBN (Anggaran Pendapatan dan Belanja Negara); 2. Penerimaan atau pemberian hibah dari atau ke luar negeri; 3. Transaksi perdagangan internasional; 4. Simpanan di bank dalam bentuk valuta asing; atau 5. Transaksi pembiayaan internasional.

Di sisi lain, penghapusan kewajiban konversi ini memberikan kemudahan bagi perusahaan yang akan menjadi sponsor bagi TKA. Terbitnya peraturan yang baru memang kerap menimbulkan pro dan kontra. Permenaker 35/2015 memang mencoba menyederhanakan prosedur pengurusan izin TKA sehingga dapat menguntungkan kalangan pebisnis di Indonesia dan TKA yang berminat untuk bekerja di Indonesia. Di sisi yang lainnya, jangan sampai peraturan baru ini bertentangan dengan peraturan perundang-undangan yang lebih tinggi

\section{Alih Pengetahuan}

Kekakuan Hubungan Pada Kemudahan Alih Pengetahuan Beberapa penelitian mengusulkan salah satu mfaktor penting yang mempengaruhi alih pengetahuan adalah hubungan antara seorang narasumber dan seorang penerima (Argote 1999; dikutip oleh Ko et al., 2005). Mengalihkan pengetahuan memerlukan interaksi yang berulangkali antar orang yang terlibat (Nonaka 1994; Ko et al., 2005). Kesuksesan interaksi bergantung pada kualitas hubungan (Ko et al., 2005). Kekakuan hubungan (arduous relationship) didefinisikan sebagai hubungan yang secara emosional sulit dan hubungan yang jauh antara sumber dengan seorang penerima, (Szulanski 1996; Ko et al., 2005), mempengaruhi kemampuan sumber mengalihkan pengetahuan yang diperlukan dan bagi si penerima untuk mempelajari serta menggunakan pengetahuan tersebut. Oleh karena itu, kekakuan hubungan antara sumber dengan penerima membawa dampak negatif terhadap keefektifan alih pengetahuan (Baum dan Ingram 1998; dikutip oleh Ko et al., 2005). H2a: Kekakuan hubungan berpengaruh negatif pada kemudahan alih pengetahuan Kemampuan mengabsorbsi (absorptive capacity)

\section{B. Simpulan}


Berdasarkan keseluruhan uraian laporan hasil penelitian ini bahwa dapat disimpulkan bahwa Alih Pengetahuan telah diatur dalam Peraturan Perundang-Undangan di Indonesia. Namun pengaturannya tersebut masih sangat bersifat umum dan sektoral. Paling tidak, terdapat tiga poin yang dapat menjelasakan pengaturan alih pengetahuan tenaga kerja asing pada jasa kontruksi di Indonesia yaitu alih pengetahuan berdasar hukum ketenagakerjaan, alih pengetahuan di bisang perbankan, dan alih pengetahuan dibidang jasa kontruksi

\section{Daftar Pustaka}

Guus Heerma Van Voss dalam Bab-Bab Tentang Hukum Perburuhan Indonesia ed. Guus Heerma Van Voss dan Surya Tjandra , (Pustaka Larasan: Denpasar, 2012),

S.F. Marbun, 2012, Hukum Administrasi Negara I, FH UII Press, Yogyakarta

Soerjono Soekanto \& Sri Mamudji, 2003. Penelitian Hukum Normatif, Suatu Tinjauan Singkat, PT. Raja Grafindo Persada, Jakarta

Tim Perbankan dan Enquiry Point, Tenaga Kerja Asing Pada Perbankan Nasional, Buletin Hukum Perbankan Dan Kebanksentralan , Volume 5, Nomor 3, Desember 2007, di unduh

http://www.bi.go.id/id/publikasi/lain/hukumperbankan/Documents/042c064ba0074ff0 aef68754e9f3e2c702_TKA2.pdf

Undang-Undang Nomor 13 Tahun 2003 Tentang Ketenagakerjaan

Undang-Undang Nomor 2 Tahun 2017 Tentang Jasa Konstruksi

Peraturan Presiden Nomor 72 Tahun 2014 Tentang Penggunaan Tenaga Kerja Asing Serta Pelaksanaan Pendidikan Dan Pelatihan Tenaga Kerja Pendamping

Peraturan Menteri Ketenagakerjaan Nomor 3 Tahun 2015 Tentang Standar Operasional Prosedur Penerbitan Perizinan Penggunaan Tenaga Kerja Asing Di Badan Kordinasi Penanaman Modal

Peraturan Menteri Ketenagakerjaan Nomor 16 Tahun 2015 Tentang Tata Cara Penggunaan Tenaga Kerja Asing

Peraturan Menteri Ketenagakerjaan Nomor 35 Tahun 2015 Tentang Perubahan Atas Peraturan Menteri Ketenagakerjaan Nomor 16 Tahun 2015 Tentang Tata Cara Penggunaan Tenaga Kerja Asing

Keputusan Menteri Tenaga Kerja dan Transmigrasi Nomor Kep.247/Men/X/2011 Tentang Jabatan Yang Dapat Diduduki Tenaga Kerja Asing Pada Kategori Konstruksi. 